\title{
3 \\ The dark lady of The Merchant of Venice
}

'The Sonnets of Shakespeare offer us the greatest puzzle in the history of English literature.' So began the voyage of Alfred Leslie Rowse (1903-97) through the murky waters cloaking the identities of four persons associated with the publication in 1609 of Shakespeare's 'sugared sonnets': the enigmatic 'Mr. W.H.' cited in the forepages as 'onlie begetter' of the poems; the unnamed 'fair youth' addressed in sonnets 1-126; the 'rival poet' who surfaces and submerges in sonnets 78-86; and the mysterious 'dark lady' celebrated and castigated in sonnets $127-52 .{ }^{1}$ Doubtless, even as Thomas Thorpe's edition was passing through George Eld's press, London's mice-eyed must have begun their search for the shadowy four; it has not slacked since.

As to those nominated as 'Mr. W.H.', the list ranges from William Herbert to Henry Wroithesley (with initials reversed) to William Harvey (Wroithesley's stepfather). In 1964 Leslie Hotson proposed one William Hatcliffe of Lincolnshire [!], while Thomas Tyrwitt, Edmond Malone, and Oscar Wilde all favoured a (fictional) boy actor, Willie Hughes. Among candidates for the 'fair youth', Henry Wroithesley, Earl of Southampton (1573-1624), appears to have outlasted all comers.

Those proposed as the rival poet include Christopher Marlowe (more interested in boys than ladies dark or light); Samuel Daniel (Herbert's sometime tutor); ${ }^{2}$ Michael Drayton, drinking partner of Jonson and Shakespeare; George Chapman, whose Seaven Bookes of the Iliades (1598) were a source for Troilus and Cressida; and Barnabe Barnes, lampooned by Nashe as 'Barnaby Bright' in Have with you to Saffron-Walden. Among the less well known pretenders are Richard Barnfield, who published the earliest praise of Shakespeare's work, ${ }^{3}$ and Gervase Markham, translator of Ariosto. ${ }^{4}$ 
Candidates for the dark lady have included Mary Fitton, mistress of William Herbert; ${ }^{5}$ the Oxford innkeeper Jane Davenant; ${ }^{6}$ and most recently 'Black Luce' (a.k.a. Lucy Negro), a Bankside prostitute nominated by G. B. Harrison. ${ }^{7}$ Surveying the arguments for each of these women, in 2004 Paul Edmondson and Stanley Wells concluded,

these theories assume any such dark lady has naturally left good documentary evidence as to her existence and identity; Shakespeare's lovers have probably left not a wrack behind them, apart from the Sonnets, and then only if the poems represent some kind of autobiography. The case will always remain open. ${ }^{8}$

But perhaps not.

\section{Rowse's dark lady and the furore she caused}

In a mere thirty-seven pages - hardly more than a preface to his edition of the sonnets - Rowse presented his 'discovery' that Shakespeare's dark lady was Emilia Bassano Lanier (1569-1645), illegitimate daughter of the Venetian converso court musician Baptiste Bassano, and sometime mistress of Henry Carey, Lord Hunsdon, cousin to Queen Elizabeth, Lord Chamberlain, and patron of the company of actors to which Shakespeare belonged. ${ }^{10}$ Though Rowse presented his finding as a 'certainty', subsequent investigators have not received it as such. Katherine DuncanJones responded: 'Romantic critics have liked to view Shakespeare surprised into sonneteering by some real-life experience. Ever since the edition of Sonnets in 1837 by James Boaden ... scholars have pursued possible personal illusions. ${ }^{11}$ Professor Duncan-Jones seems to infer that Shakespeare's 'fair youth' and dark lady are literary creations which leapt full-formed from poet's imagination. But, really, can this be so?

Ilona Aiello recognizes that the sonnets are imbricated in Shakespeare's life, embodied in particular lived circumstances that are known to the addressee but concealed from us'. ${ }^{12}$ Garry O'Connor believes Shakespeare's cunning description of the dark lady was intentionally designed to throw his contemporaries off the scent: 'Lanier was a bit too dark to be the real thing. Moreover, Shakespeare would surely never have rendered her so literally ... especially as he was supposed to have inherited her from his patron, 
the Lord Chamberlain Hunsdon, one of Elizabeth's most formidable warriors and protectors. The aristocracy were touchy about family scandal. ${ }^{13}$ On the contrary, Ms Aiello shrewdly argues that only some concealment of the players' identities is intentional. Some is due to the author's confusion: 'Much of what happens in the dark lady sonnets ... is so intimate, so sexual, so fraught with desire and potential scandal that Shakespeare would rather not say - exactly. To make matters even more baffling, there is a great deal he does not know and cannot understand about the man and the lady, and their relationship to each other.' ${ }^{14}$ She offers a libidinous and persuasive explanation of why the faces behind the masks are obscured:

The dark lady sonnets draw us into a world where passion distorts judgment, where duplicity and role-playing are a mark of sophistication, and where it is difficult to distinguish truth from lies. Shakespeare's attempts to see and present her accurately are foiled by his recognition that nothing she says to him and nothing he says about her can be trusted; the more he tries to report what is ... the more desire befuddles judgment. ${ }^{15}$

Despite such caveats, the depth and murkiness of passages through the sonnets have not deterred literary spelunkers.

\section{Emilia and her rivals}

Emilia Lanier is only one of the women 'discovered' as the inspiration for Shakespeare's dark lady. Stephen Booth scoffed:

Sonnets 127-152 include several that refer to or address a woman (or, improbably, some women) of dark complexion and whore-like habits. She, like the male friend ['fair youth'], may be a literary creation; if Shakespeare was talking about real people and events, we have no clue whatsoever as to the woman's identity. Speculation on her identity has ranged from wanton to ludicrous and need not be illustrated. ${ }^{16}$

Yet in our present context it won't be entirely ludicrous to interrogate a few of the candidates nominated as the dark lady.

Arthur Acheson believed she was Mistress Jane Davenant (d. 1622), keeper of the St George inn near Oxford, ardently visited by Shakespeare during his trudges between Stratford and London. Acheson also saw reflections of Jane in the Courtesan of The Comedy of Errors and in Cleopatra - and he wasn't the 
only one. ${ }^{17}$ 'Agatha Christie wrote a letter to The Times wherein she attributes the character of Cleopatra, written a dozen or more years ... [after the dark lady] affair, to Shakespeare's memory of Emilia Lanier.' ${ }^{18}$ Biddy Darlow [sic] settled on Elizabeth Vernon, wife of Southampton, ${ }^{19}$ and Hugh Calvert wrote that Leslie Hotson credited G. B. Harrison with

first identifying (though very tentatively) Lucy Negro [a.k.a.] Abbess de Clerkenwell as the dark lady, also the discredit of believing the lady a blackamoor. Black Luce was of course no more an Ethiope than the Black Prince. Lucy was by 1594 (some five or six years after the sonnets according Hotson's dating) set up as the 'madam' of a house [brothel] in Clerkenwell. The period of Shakespeare's wretched infatuation is fixed by Leslie Hotson with the rest of the sonnets in 1588 or ' $89 .{ }^{20}$

Just as notions about 'Black Luce' have been discarded, Hotson's dates for the sonnets have been superseded; the scholarly consensus now dates them to $1592-94$, or perhaps as late as 1596 . The date ad quem is thought to be set by Frances Meres' reference in 1598 to the circulation of Shakespeare's 'sugared sonnets among his private friends'. ${ }^{21}$

Another dark lady seeker, F. E. Halliday, began his sortie by admitting the obvious: 'There have been many guesses, but nobody really knows who she was. It seems reasonable to identify her with a mistress stolen from Shakespeare by his friend.' He then volunteered further candidates: 'Ivor Brown thinks she was Anne Whateley; perhaps "Rosalind" is a clue: the Rosalinds of Romeo and Juliet and of Love's Labour's Lost are both black beauties.'22 All such finger-pointing culminated in Rowse's announcement in 1963 that Emilia Lanier was the dark lady. Since which date criticism of and hostility towards Rowse's conclusion have never flagged.

\section{Rowse vs. his critics}

In the latter years of the twentieth century the trend among contemporary critics was ruthlessly to weed the author out of his work. Roger Prior observed that 'Modern literary criticism is dedicated to removing the author from the text ... The author's thoughts and intentions can never be known, it is claimed, and are in any case quite irrelevant to our understanding of his work' - an 
extraordinary statement for a serious critic of literature. ${ }^{23}$ Susanne Woods believes that 'It is this doctrine that is threatened by Rowse's discovery and fuels much of the hostility to it.' For her part, Woods not only denies Rowse's 'discovery' but asserts that what inspired Shakespeare was not an individual woman but a type - another remarkable notion:

To those of us steeped in the sonnet tradition much of this language seems a witty response to the conventional virtuous beauty of courtly love ... The whole point of sonnet writing was to weave variations on common themes and to overgo predecessors; whether or not a real dark lady inspired Shakespeare's sonnets, they're an immediately recognizable (often delightful, sometimes provocative) response to a popular and well understood set of conventions. ${ }^{24}$

But even if Shakespeare's sonnets were merely an exercise in the form (which they are not), that hardly precludes them being inspired by real and familiar persons.

Katherine M. Wilson went one better, characterizing the dark lady and her sonnets as 'pure parody': 'Indeed nothing is easier to show than that they are parodies. [T] here can be no mistake about Sonnet 130 . This could be nothing other than parody. ${ }^{25}$ Wilson contends that some of the sonnets which Shakespeare parodied are readily identifiable. Sonnet 127 'is a direct and incontrovertible comment on Sydney's seventh in Astrophil and Stella. Black eyes were not the correct sort in sonnet convention, but the real Stella had this so Sydney poetizes them in sonnet VII. ${ }^{26}$ But commenting on a pre-existing sonnet does not necessarily make 127 a parody. Taking her argument a bridge too far, Wilson believes that Shakespeare's sonnets parody the genre itself: 'Like 130, sonnet 141 parodies not one particular sonnet, but the convention as a whole. ${ }^{27}$ The difficulty with Wilson's argument is two-fold: firstly, parody does not preclude a real female being Shakespeare's inspiration; secondly, where else in the canon has the poet written a parody which is merely a parody and nothing but? Nowhere.

Some of Rowse's sternest critics acknowledge that Lanier may have been a dark lady even if not the dark lady. Woods concedes: 'It is certainly possible. David Lasocki has found a report from 1584 that describes two of her cousins as a little black man who was booted (probably Arthur Bassano) and a tall black man ... [which] must refer to their dark complexion and black hair, typical 
of Italians but rare in England at the time. ${ }^{28}$ Woods is sufficiently intrigued to wonder whether Lanier had contact with Shakespeare and/or his works, and whether the experience might have encouraged her own volume of poetry, Salve Deus Rex Judaeorum (London, 1611).

It would be interesting to know whether Lanier and Shakespeare ever met. Whether they did or not, Lanier was likely to have read his narrative poems, since Salve Deus shows her to have been interested in the genre (sometimes called epillyon, a nineteenth-century coinage meaning 'little epic'), and to have been reading others in the same general type. She may also have attended or read his published plays, but I leave that debate to others. ${ }^{29}$

While there is no evidence that Lanier knew Shakespeare or his work, she could hardly have been unaware of him. Jacobean London was little more than a large town with a population of some 200,000 - equivalent to modern Yonkers, New York, or the London Borough of Harrow - that is, small enough that anybody who was anybody knew everybody who was anybody. Public entertainments were limited to theatrer, bear-baiting, pubs, whorehouses, and sermons; plays in quarto were cheap and relatively plentiful; thanks to the roles Shakespeare wrote for him, Richard Burbage was the Elizabethan equivalent of a rock star. Shakespeare was also a celebrated performer. Is it conceivable that a woman of Emilia's means and education would have been deaf and blind to Shakespeare's works and the man himself?

\section{The dark lady's promiscuity}

Another issue which has provoked cries of 'Foul!' from the defenders of Emilia's honour is the dark lady's apparent liberality in bestowing sexual favours. Woods insists there is 'no convincing evidence she [Lanier] was promiscuous'. ${ }^{30}$ Duncan-Jones is equally indignant: 'The monstrously sexist assumption that a woman who was sufficiently attracted to one man to consummate her love without marriage would have been prepared to have sex with anyone ... crucially underpins Rowse's support for Emilia Lanier, which seems to depend on the belief that a woman who was Lord Hunsdon's mistress would be willing to have sex with anyone including, therefore, Shakespeare. ${ }^{31}$ On the contrary, the mistress of a rich and powerful grandee would have multiple reasons for being 
choosy about her partners. And having sex with a celebrated poet, playwright, and actor is hardly having sex with 'anyone'.

By contrast, Garry O'Connor is less judgemental and more realistic. He notes that Simon Forman, who claimed to have 'supped with her [Lanier] and stayed all night' describes her as a harlot who "useth sodomy". [W] hile he felt all the parts of her body "willingly" and often kissed her, she would not "halek" [have sex] with him (a halek is a little fish used for making pickle; to be in a pickle is to be in a hole).' O'Connor believes this 'a convincing picture of the Elizabethan coquette, especially of how such a creature's sexual dalliance never felt the need to go the whole way in terms of intercourse. Elizabethan men were great fumblers and feelers of women.' 32

On the other hand, David Bevington considers the issue of the dark lady's coquetry from a purely practical perspective. Hunsdon was a powerful and influential man as well as a proven warrior and companion of 'sword and buckler' men. He was also in a position to influence Shakespeare's career as dramatist and actor. 'One might wonder if Southampton and Shakespeare would have ... thought it prudent to pursue a lady who, in 1592-94 (Rowse's years for the sonnet narrative), was for the most if not all this period the mistress of the Lord Chamberlain?' ${ }^{33}$ From what we know about Shakespeare, who seems to have been a man of considerable discretion, ${ }^{34}$ would he have jeopardized his career by risking the jealous ire of a magnate like Hunsdon? One hardly thinks so.

Indeed, René Weis infers that Shakespeare was sufficiently prudent to embark on his affair with Emilia after her marriage in October 1592 to the court musician and her cousin once-removed Alfonso Lanier (d. 1613). If the affair began after the birth of Henry Lanier (1593-1633), this would push its dates to 1593-94 or 1595. Though Shakespeare indulged enthusiastically in their adulterous affair, Weis notes that both partners were married and that the poet expressed feelings of guilt in Sonnet 152: 'In loving thee thou know'st I am forsworn, But thou art twice forsworn, to me love swearing, In act thy bed-vow broke and new faith torn, In vowing new hate after new love bearing.' 'The poet's confession ... must refer to his marriage vows. ${ }^{35}$ Can we not see how the poet's sense of being both betrayer and betrayed would constrain and inflame his appetite for his dark lady?

Reviewing such politely couched opinions on the allure of Shakespeare's dark lady and their furious, exalting relationship, one 
is drawn to the conclusion that many of his commentators have led lives of quiet deprivation, never having enjoyed a love affair with a truly bad woman or frivolous man. They evince no feeling for that all-consuming, frantic passion that consists of equal parts love and rage, orgasmic joy, and searing pain. Anyone privileged to have suffered such an affair can understand the turbulent mood-swings in Shakespeare's sonnets. Had his dark lady not been promiscuous as well as a liar, cheat, seductress, casual fornicator, and, thereby, beyond the sole possession of any one man - she wouldn't have been nearly so desirable. To make a good-bad thing better (worse), Shakespeare was married, the father of three, and perhaps bisexual.

In sum: Shakespeare's dark lady was everything he wanted and couldn't-shouldn't have. His sonnets should be recognized for what they are: the poetry of obsession.

\section{Emilia Lanier, poet}

Whether or not she was the dark lady, Emilia's career was extraordinary almost from beginning to end. Born illegitimate, the penniless orphan was swept into manorial luxury, educated better than virtually all her female contemporaries, seduced by one of the greatest men in the realm. Perhaps the lover and inspiration of the greatest poet ever to write in English, she outlived them all and died in 1645, aged seventy-six, having witnessed the beginning of the civil war that would topple the monarchy. She also published in 1611 the first significant book of poetry by an Englishwoman, Salve Deus Rex Judaeorum, and could lay claim to the title of first professional female English poet. Her book begins with a series of poetical dedications to a number of the leading ladies of the realm which preface a lengthy meditation on Christ's Passion from a decidedly feminist perspective.

Lanier offers a passionate defence against prevailing misogynist views of women's weakness. Although she admits that a 'Woman writing of divinest things' is 'seldome seene', ${ }^{36}$ she boldly offers a polemical counternarrative to biased accounts of women in biblical history: 'I have written this small volume, or little booke, for the generall use of all virtuous Ladies and Gentlewomen of this kingdome ... And this have I done, to make knowne to the world, that all women deserve not to be blamed. ${ }^{37}$ Lanier portrays biblical women as instruments sent by God to counter sinful men. Pontius 
Pilate's wife serves as one of the text's central emblems of spiritual virtue for her efforts to prevent the Crucifixion. Pilate's wife delivers a diatribe that rates the sin of Eve (foremother of female weakness) less egregious than the evil deeds of Christ's male crucifiers. ${ }^{38}$

The modern reader can perceive the magnitude of Emilia's task in defending women only by placing it in apposition to the remarkable fourteen-hundred-year misogynist tradition of the Church. In the third century AD Tertullian addressed women at large:

And do you not know that you are Eve? God's sentence hangs still over all your sex and His punishment weighs down upon you. You are the devil's gateway; you are she who first violated the forbidden tree and broke the law of God. It was you who coaxed your way around him [Adam] whom the devil had not the force to attack. With what ease you shattered that image of God: Man! Because of the death you merited, even the Son of God had to die. ... Woman, you are the gate to Hell. ${ }^{39}$

In the fourth century Augustine of Hippo demanded: 'What is the difference whether it is in a wife or a mother? It is still Eve the temptress we must beware in any woman. ${ }^{40}$ The notion that Eve and, therefore, all women were responsible for the Fall of Man was still commonplace in the sixteenth century; in 1558 John Knox railed against their sex: 'your free will [sexual appetite] has brought yourself and mankind into the bondage of Satan'. ${ }^{41}$

So when Emilia took up the cudgels in the name of womanhood, she was tangling with a millennial tradition of Christian misogyny. In her 'To the Virtuous Reader' she rises to a strident defence of women against calumnies 'practised by euell disposed men, who forgetting they were borne of women, nourished of women, and that if it were not by the means of women, they would be quite extinguished out of the world ... doe like Vipers deface the wombes wherein they were bred' ${ }^{42}$ Extraordinary rhetoric for the Elizabethan age.

In what would be a thrilling - if proven - hypothesis, Kate Emery Pogue suggests that the publication of Salve Deus in 1611 was Emilia's rejoinder to the lurid portrait of her which appeared in Shakespeare's sonnets two years earlier: 'Emilia's poems, published in 1611 and strongly defending women, can be read as a riposte to the slanderous characterization. ${ }^{43}$ If London's mice-eyed decipherers had recognized Emilia as the dark lady, perhaps such a response 
was warranted. Pogue's is an appealing notion even if unsupported (so far).

In a certain sense, Rowse was enemy to his own thesis; he misread Simon Forman's description of a 'very brave' woman as 'very brown', and mistook her husband's name as Will when it was Alfonso. More generally, Rowse's close reading of the sonnets is so persnickety as to imply we can recover whether the toast was burned at breakfast. We may never know if there is any validity to Rowse's inference. But there are broader, tantalizing clues which suggest that Shakespeare and the lady enjoyed the lusty if tempestuous relationship described in the poems. To those already known this chapter proposes to add one more: that Emilia Bassano Lanier provided the model for Shakespeare's Jessica in The Merchant of Venice.

\section{A dark Venetian Jew}

When Baptiste Bassano, Venetian converso Jew and court musician, died in 1576, he left his daughter Emilia penniless; she would receive a legacy of $£ 100$ only on attaining the age of twenty-one. For reasons unknown Emilia was taken into the household of Susan Bertie, Countess of Kent (b. 1554); whether as a servant or a ward is still debated. A proto-feminist, Bertie believed that girls should be as well educated as boys. Emilia learned Latin and read the classics, surely along with continuous lessons in poise, grooming, courtly manners, witty conversation, and other ladylike skills - perhaps including mastery of the virginals, a suitable pastime for a musician's daughter.

With her dark skin, raven hair, fine education, and courtly manner Emilia must have been a most desirable young woman. Within months of her mother's death in 1587, eighteen year-old Emilia became the mistress of one of the greatest men in England: Henry Carey, aged sixty-one and old enough to be her grandfather. ${ }^{44}$ In the dedication of Salve she remembered her patroness as 'the Mistris of my youth, The noble guide of my ungovern'd days'. ${ }^{45}$

According to the diary of Simon Forman (1552-1611), Carey delighted in his young lover and lavished her as well as ravished her. On 3 June 1597 Forman noted, 'She was maintained in great pomp [and] hath $40 £$ a yere', a substantial stipend. ${ }^{46}$ When in 1592 Emilia became pregnant, Carey married her off to her slightly distant 
cousin Alfonso Lanier, also a court musician. Forman recorded on 17 May 1597, 'yt seams that being with child she was for colour married to a minstrel'. ${ }^{47}$ When she bore a son in 1593, plucky Emilia named him Henry, as either a tribute to his natural father or a prod.

As noted, it seems unlikely that Shakespeare would have presumed to share the favours of the mistress of his patron Carey, an old lion inclined to 'sword and buckler men'. ${ }^{48}$ That could have been a dangerous game. However, the actor-playwright may well have met Emilia during her liaison with the Queen's cousin, and then offered his services once she was committed to an unwelcome marriage to a poor player and delivered of her child. If Emilia was, in fact, Shakespeare's dark lady, she may have become his mistress circa 1594-95, which accords with the putative dates of the writing of the sonnets.

Her marriage proved a sorry one for Emilia, but a brilliant coup for Alfonso; according to Forman, his bride was 'was welthy to him that married her in monie \& Jewells ${ }^{49}$ But a subsequent entry recorded that her dowry had been quickly spent and her marriage a disappointment: 'a nobleman that is ded [Carey] hath Loved her well $\&$ kept her and did maintain her longe but her husband hath delte hardly with her and spent and consumed her goods and she is nowe ... in debt'. ${ }^{50}$

Somehow, resilient Emilia not only survived Alfonso and her marriage, but flourished intellectually if not financially. In 1611 she published Salve Deus Rex Judaeorum, still considered a work of distinction. Though her dowry had been squandered, her education in the household of Susan Bertie had not; after her husband's death in 1613 Emilia started a school for children of the nobility at St-Giles-in-the-Fields (the venture failed). ${ }^{51}$

\section{Shakespeare's Venetian-Jewish play}

That Shakespeare had a passion for Italy seems beyond doubt. From his earliest comedy, Two Gentlemen of Verona, to his last solo creation, The Tempest, Shakespeare's plays are dotted with Italian locations and characters. Many scholars believe Shakespeare read (and may have spoken) Italian; ${ }^{52}$ I've suggested elsewhere that the playwright knew Bandello's Giulietta e Romeo in its Italian original. ${ }^{53}$ It also seems likely that Shakespeare knew one or more sources of 
Twelfth Night - Gl'ingannati (1537) and/or Nicuola and Lattantio (1554) - in either Italian or French translation. Did Shakespeare acquire his Italian from or because of Emilia? And how did she come by her skill at poetry? Was it at the knee of the Countess or through her own later reading? Or was she perhaps inspired and tutored by the greatest poet of the age? Alluring as those speculations are, one must remember that even the pair's mutual acquaintance is unsubstantiated. As David Bevington asked, 'why doesn't Shakespeare hint at a husband who abuses his wife and spends all the money she brings in from the aging great lord that keeps her, as evidently was the case with Lanier and his wife?'54

I suggest that Shakespeare did exactly that - but not in the sonnets. Instead, the playwright wrote into his The Merchant of Venice a portrait of wilful Emilia and her failed marriage which, if merely coincidental, is uncannily true to life.

Shakespeare's Jessica is a Venetian Jew kept in the household of a wealthy elderly man. Emilia was twice kept; once by Carey, once by the Countess. In 2.3 we meet Jessica colluding with the servant Lancelet to effect her elopement. ${ }^{55}$ That done, in her next breath she announces her intention to forsake her birthright: 'Alack, what heinous sin is it in me To be ashamed to be my father's child! But, though I am a daughter to his blood, I am not to his manners' (16-18). The received (and deeply unsatisfying) interpretation of these lines is that Jessica deplores being a Jew and daughter to a money-lender. But Jessica nowhere shows disdain for Judaism per se, nor does she exhibit any hint of Christian religiosity. Besides, money-lending was one of the few legitimate occupations open to the Jews of early modern Venice, and Shylock appears to be a respected member of the Jewish community. ${ }^{56}$

However, if one puts Jessica's words into the mouth of young Emilia Bassano, strong resonances become audible. Emilia was a bastard, and a bastard bore the sin of her conception to the tenth generation according to Deuteronomy 23:2, a book which came in for a good deal of close reading under Queen Elizabeth's father. ${ }^{57}$ So a bastard had the best possible reason to declare she was 'ashamed to be my father's child'. Furthermore, though Emilia was 'daughter to the blood' of Baptiste, she had been raised and educated in the household of a countess; surely, she no longer shared his 'manners'. By naming the spendthrift lover of Merchant 'Bassanio', was Shakespeare preparing us to receive his portrait of 
Emilia née Bassano as Jessica? The names 'Emilia', 'Bassano', and their cognates have long careers in the canon, and Shakespeare created another Emilia in his other Venetian play, Othello. Circa 1592 - at the very moment when Emilia's liaison with Carey was ending and she was being shopped to Alfonso - both an Aemilius and a Bassianus appear in Titus Andronicus. ${ }^{58}$ In The Taming of the Shrew, arguably written in 1593, a year after Emilia's troubled marriage to Alfonso, the names of her husband (Alfonso), her father (Baptista), herself (Emilia) appear. Did Emilia's nuptials provide Shakespeare's inspiration for the alliance of his shrewish Katherine with Petruchio? In the final act of Merchant her new husband calls Jessica 'little shrew' (5.1.21).

In Merchant 2.6 Jessica elopes with Lorenzo. But first she lowers down to him a casket of money and jewels, then pauses to 'gild myself With some more ducats' (50-1). Exactly as Emilia did, Jessica left her old man's household laden with riches to be married to a 'Venetian' boy (though probably born in Rouen, Alfonso was Emilia's cousin). After she has made her escape, we learn of Jessica by hearsay. And what we hear is a study in profligacy. Salanio reports that Jessica made off with 'two sealed bags of ... double ducats' and 'two rich and precious stones' (2.18-20). Shylock learns worse from Nathan: 'Your daughter spent in Genoa, as I heard, one night fourscore ducats' (3.1.98-9). Worse even than that, one of Antonio's creditors 'showed me a ring that he had of your daughter for a monkey' (107-8) which sends Shylock into a paroxysm of grief: 'Thou torturest me, Tubal. It was my turquoise: I had it of Leah when I was a bachelor. I would not have given it for a wilderness of monkeys' (109-11).

Intriguingly, in each report it is 'your daughter', Jessica - not her new lord and husband Lorenzo, and not 'they' together - who squanders Shylock's ducats and trades away his intended's precious gift. If Jessica is the spendthrift of the pair - if she herself wasted her self-bestowed dowry - is that a glance at the fortune which pursued Emilia and her poorish husband Alfonso? Was Forman mistaken (or misled), and was it Emilia herself, accustomed to living on $£ 40$ a year plus gifts of jewellery and other emoluments and not Alfonso - who squandered the endowment Carey made when he passed her off to her cousin? In 3.2 Jessica and Lorenzo are ensconced in the palatial manor at Belmont while Portia and Nerissa ride to the rescue of Antonio. Whether the newlyweds chose 
to go there - or had to go there because Jessica's stolen dowry was exhausted - is a nice question.

Jessica is now as well set up as, say, Emilia in the household of the Countess of Kent. But her reception in Belmont is not without incident. Greeting her, Gratiano jokes, 'But who comes here? Lorenzo and his infidel?' (217), implying that the stain of Jessica's former religion - exactly like the stain of Emilia's bastardy - wasn't entirely washed away by the baptism she would have had to undergo before she could marry Lorenzo. Despite this momentary flash of prejudice it seems that once settled in Belmont, Jessica has landed on Easy Street. But no.

In 5.1 we discover Jessica and Lorenzo together before the Belmont mansion as a rancorous dialogue ensues. It's night. Lorenzo begins:

The moon shines bright. In such a night as this, When the sweet wind did gently kiss the trees And they did make no noise, in such a night Troilus, methinks, mounted the Trojan walls And sighed his soul toward the Grecian tents, Where Cressid lay that night. (1-6)

Readers of Chaucer's Troilus and Criseyde or Shakespeare's rewrite would know that while Troilus was mooning over her, Cressida lay with the unappetizing Greek, Diomede. Lorenzo's sweet-sounding words don't conjure an image of love but of a deflowered young woman seizing on the protection of an older man, as Emilia did with Carey.

To Lorenzo, Jessica replies: 'In such a night Did Thisbe fearfully o'ertrip the dew, And saw the lion's shadow ere himself; And ran dismayed away' (6-9). Those who knew the legend or had seen Shakespeare's A Midsummer Night's Dream would know that Thisbe's flight led directly to the deaths of Pyramus and herself.

The young Venetian couple's conversation wanders on to Dido (who killed herself because of the inconstancy of Aeneas) and Medea (betrayed by Jason, she murdered him, his new love, the girl's father and everyone else within reach before banishing herself to exile or death).

Then things turn personal.

Lorenzo calls his wife a thief and profligate: 'In such a night Did Jessica steal from the wealthy Jew, And with an unthrift 
love did run from Venice As far as Belmont' (14-17). Is this a wink at Alfonso's part in the squandering of Emilia's dowry? Jessica returns the compliment, accusing Lorenzo of lying 'with many vows of faith, And ne'er a true one' (17-20) to win her. Lorenzo denies her allegation, saying, 'In such a night Did pretty Jessica, like a little shrew, Slander her love, and he forgave it her' (20-2). Jessica isn't done yet; she declares, 'I would out-night you did nobody come' (23) - I'd go you one better but here comes an intruder.

This is not a happy couple. Indeed, we're given to understand that though Lorenzo still lusts for her, he's lost his luster for her. Jessica has made a bad marriage.

In case we have missed the point, a few moments later Lorenzo waxes rhapsodical:

Look how the floor of heaven

Is thick inlaid with patines of bright gold.

There's not the smallest orb which thou behold'st

But in his motion like an angel sings,

Still quiring to the young-eyed cherubins.

Such harmony is in immortal souls ... (58-63)

This is the cue for musicians to enter - just as Emilia's father Baptiste and his colleagues must have been summoned from below stairs to serenade a gaggle of courtiers. Lorenzo cries to them, 'Come, ho! and wake Diana with a hymn, With sweetest touches pierce your mistress' ear, And draw her home with music' (66-8). But when they begin to play, Jessica declares, 'I am never merry when I hear sweet music' (69). It's the dull sound of the other shoe dropping. Like Emilia Bassano, palmed off on a poor court musician, Shakespeare's Jessica has recognized her marriage as a bitter mistake. And if Emilia became Shakespeare's mistress during her unsatisfying marriage with Lanier, he would have heard an earful of disappointment in her pillow-talk.

\section{The Jewish lady of the sonnets}

If Shakespeare's portrait of a wilful and bitterly disappointed Jessica was inspired by Emilia and her marriage, this insight resonates with several clues to the identity of the dark lady in his sonnets. In Sonnet 127: 
In the old age black was not counted fair,

Or if it were, it bore not beauty's name;

But now is black beauty's successive heir,

And beauty slandered with a bastard shame.

(1-4, my emphasis)

Shakespeare's Cleopatra will lament that she is 'black', meaning oldish and unhandsome. But in this sonnet the very personification of beauty is both dark-skinned and raven-haired - and also 'slandered with a bastard shame', the stigma Emilia Bassano bore. ${ }^{59}$

In Sonnet 130, the focus is sharpened to bring out the details of the dark lady's presence:

My mistress' eyes are nothing like the sun;

Coral is far more red, than her lips red:

If snow be white, why then her breasts are dun;

If hairs be wires, black wires grow on her head.

I have seen roses damasked, red and white,

But no such roses see I in her cheeks;

And in some perfumes is there more delight

Than in the breath that from my mistress reeks. (1-8)

The first and second couplets could describe any dark-complected woman. But the latter's allusion to black, wiry hair seems to glance at a Mediterranean type, particularly in the presence of 'damasked', a word signifying the complex woven fabrics which originated in eleventh-century Damascus, Syria, a city ruled in biblical times by Jewish Israelites before being annexed to the Assyrian Empire in 732 BC. The final couplet which alludes to the 'breath that from my mistress reeks' may be a wink at the foetor Judaicus, that distinctive odour attributed to Jews since the Middle Ages, which perhaps derived from the garlic in their diet. Garlic was unknown in England before the mid-sixteenth century. 'Reek' as a noun is a synonym for foetor, a Latin word that retains its original form in English. In her Blood Relations Janet Adelman wrote that Jews 'are generally depicted throughout the Middle Ages as physically unmistakable, with red or black curly hair, large noses, dark skin, and the infamous foetor Judaicus, the bad smell that identified them as Jews. ${ }^{60}$ Garlic was a staple of the diet of Jews dating back to the Egyptian enslavement. ${ }^{61}$ 'In Talmud Yerushalmi Tractate Megillah 75a, Ezra [the Scribe] urged men to eat garlic on Shabbat as it was an aphrodisiac and would hence help re-populate Israel after the partial return 
from the Babylonia exile. ${ }^{62}$ In his Shakespeare and the Jews, James Shapiro noted that the belief that Jews emitted an unpleasant odour was 'unusually persistent' among Elizabethans. ${ }^{63}$ Martin Luther, who would in later life turn against the Jews and lay down eight rules for their expulsion from Germany (all of which were adopted during the Third Reich in 1933-45), wrote in his more conciliatory early work That Jesus Christ was Born a Jew (1523): 'deal gently with them [the Jews] and instruct them from Scripture; then some of them may come along [be converted]. Instead of this we are trying only to drive them by force, slandering them, accusing them of having Christian blood if they don't stink, and I know not what other foolishness. ${ }^{64}$ The lady of Sonnet 130 with dark sin, black wiry hairy, and halitosis need not be a Jew. But if she were, the description is remarkably apt. If Emilia's patrimony and misfortune inspired Jessica and her poor choice of Lorenzo in Shakespeare's The Merchant of Venice, the vocabulary of Sonnet 134 assumes a new and vibrant hue:

So now I have confessed that he is thine, And I myself am mortgaged to thy will, Myself I'll forfeit, so that other mine Thou wilt restore to be my comfort still: But thou wilt not, nor he will not be free, For thou art covetous, and he is kind; He learned but surety-like to write for me, Under that bond that him as fast doth bind.

The statute of thy beauty thou wilt take, Thou usurer, that put'st forth all to use, And sue a friend came debtor for my sake; So him I lose through my unkind abuse. Him have I lost; thou hast both him and me: He pays the whole, and yet am I not free. (1-14, my emphasis)

So much of the drama of Merchant is pre-figured in the language of this poem that it seems to demand a connection between his dark lady and the loansharking world of the play Shakespeare wrote in 1596, perhaps within months of writing Sonnet $134 .{ }^{65}$ And finally we come to Sonnet 128:

How oft when thou, my music, music play'st,

Upon that blessed wood whose motion sounds

With thy sweet fingers when thou gently sway'st 
The wiry concord that mine ear confounds,

Do I envy those jacks that nimble leap,

To kiss the tender inward of thy hand,

Whilst my poor lips which should that harvest reap,

At the wood's boldness by thee blushing stand!

To be so tickled, they would change their state

And situation with those dancing chips,

O'er whom thy fingers walk with gentle gait,

Making dead wood more bless'd than living lips.

Since saucy jacks so happy are in this,

Give them thy fingers, me thy lips to kiss. (1-14)

If we could confirm that Emilia Bassano Lanier had mastered the virginals while in the household of the Countess of Kent - as privileged young women were likely to do, particularly a musician's daughter - I imagine some would consider Emilia's identity as the Dark Lady settled. ${ }^{66}$ I already do.

Recognizing that characters and passages in Shakespeare's plays were inspired by people he knew and loved opens a window into the emotional life and mind of the playwright. As we reconsider his Twelfth Night, or What You Will, we'll not only marvel at the intellect he marshalled to amuse his Queen and her courtiers. We'll feel the warmth he lavished on friends, his disdain for enemies, and the pangs of Shakespeare's personal losses and the drama of his hopes for heaven.

\section{Notes}

1 A. L. Rowse, Shakespeare's Sonnets (New York: Harper \& Row, 1963), vii.

2 Among Pembroke's advocates: Rowse, ibid., 138-64; John Dover Wilson, An Introduction to the Sonnets of Shakespeare (Cambridge: Cambridge University Press, 1964), 72-90; Katherine Duncan-Jones, Shakespeare's Sonnets, The Arden Shakespeare, Series 3 (London: Bloomsbury, 2010), 54-7.

3 Leo Daugherty, William Shakespeare, Richard Barnfield, and the Sixth Earl of Derby (London: Cambria Press, 2010), 167. Barnfield admired Venus and Adonis in 1598 before Shakespeare was known to be its author.

4 F. E. Halliday, A Shakespeare Companion 1564-1964 (Baltimore: Penguin, 1964), 141-2. 
5 First proposed in Thomas Tyler's edition of the Sonnets (London: Thomas Nutt, 1890), and later championed by Frank Harris in his play Shakespeare and his Love (London: Frank Palmer, 1904) and his book The Women of Shakespeare (New York: Mitchell Kennerley, 1911).

6 Shakespeare was variously claimed as natural father or godfather to Jane's son, William, born in 1606. See Arthur Acheson, Mistress Davenant (London: Bernard Quaritch, 1913). And he was recently championed by Duncan Salkeld, Shakespeare among the Courtesans (Farnham: Ashgate, 2012).

7 G. B. Harrison, Shakespeare at Work (London: Routledge, 1933), 310.

8 Paul Edmondson and Stanley Wells, eds, Shakespeare's Sonnets (Oxford: Oxford University Press, 2004), 26.

9 A. L. Rowse, Shakespeare, the Man (New York: Harper Collins, 1973); A. L. Rowse, ed., The Poems of Shakespeare's Dark Lady (New York: Clarkson N. Potter, 1979). For a boisterous and helpful affirmation of Rowse and Emilia, see Martin Green, 'Emilia Lanier IS the Dark Lady'. English Studies 87.5 (October 2006), 544-76. For the dark lady as figment of Protestant imagination see Hugh Richmond, 'The Dark Lady as Reformation Mistress', The Kenyon Review 8.2 (1986), 91-105. G. B. Shaw's play The Dark Lady of Shakespeare's Sonnets (1910) is a pastiche appeal for the building of a National Theatre on the Bankside (twenty-eight years later he got his wish).

10 The spelling of Lanier's name in sources is given as Aemilia or Emilia, and Lanier or Lanyer. On the basis of spelling in Lorna Hutson, 'Lanier [née Bassano], Emilia (bap. 1569, d. 1645)', Oxford Dictionary of National Biography, rev. first published 2004; online edition, January 2012, http://dx.doi.org/10.1093/ref:odnb/37653 (accessed 16 March 2013). I have standardized these throughout as Emilia and Lanier.

11 Katherine Duncan-Jones, ed., Shakespeare's Sonnets, The Arden Shakespeare (London: Bloomsbury, 2010), 49.

12 Ilona Aiello, 'Rethinking Shakespeare's Dark Lady', in Michael Schoenfeldt, ed., A Companion to Shakespeare's Sonnets (Oxford: Blackwell Publishing, 2007), 294.

13 Garry O'Connor, William Shakespeare: A Life (London: Houghton \& Stoddard, 1991), 144.

14 Aiello, 'Rethinking', 295.

15 Ibid., 299.

16 Stephen Booth, Shakespeare's Sonnets (New Haven: Yale University Press, 1978), 549.

17 Acheson, Mistress Davenant, 187, 194.

18 Rowse, Dark Lady, 29.

19 Biddy Darlow, Shakespeare's Lady of the Sonnets (London: Palantype Organization, 1974). 
20 Hugh Calvert, Shakespeare's Sonnets and Problems of Autobiography. (London: Merlin Books, 1996), 205.

21 Frances Meres, Palladis Tamia: Wit's Treasury (London, 1598).

22 F. E. Halliday, A Shakespeare Companion 1550-1950 (New York: Funk and Wagnalls, 1952), 610.

23 Roger Prior and David Lasocki, The Bassanos: Venetian Musicians and Instrument Makers in England, 1531-1665 (Menston: Scolar Press, 1995), 115-16.

24 Susanne Woods, Lanier: A Renaissance Woman Poet (Oxford: Oxford University Press, 1999), 92.

25 Katherine M. Wilson, Shakespeare's Sugared Sonnets (London: Allen and Unwin, 1974), 83.

26 Ibid., 88.

27 Ibid.

28 Woods, Lanier, 98.

29 Ibid. Also see Susanne Woods, ed., The Poems of Aemilia Lanier: Salve Deus Rex Judaeorum (New York: Oxford University Press, 1993).

30 Woods, Lanier, 98.

31 Duncan-Jones, Sonnets, 53.

32 O'Connor, Shakespeare, 143. O'Connor cites a number of reasons why a coquette (or any fastidious Elizabethan) would abstain from intercourse: 'Deficiencies in personal hygiene and widespread gynecological disorders made intercourse often disagreeable or uncomfortable; rotting teeth, bad breath, nauseating skin conditions and constant stomach complaints cannot have helped - and these are apart from the ever-present pox. The man rarely washed anything but his face, neck, hands, and teeth, while a woman neglected her "concealed parts" witness the Earl of Rochester's later plea: "Fair nasty nymph, be clean and kind And all my joys restore By using paper still behind And sponges for before."' Ibid., 144.

33 David Bevington, 'A. L. Rowse's Dark Lady', in Marshall Grossman, ed., Aemelia Lanier: Gender, Genre, and the Canon (Lexington, KY: University Press of Kentucky, 1998), 21.

34 Henry Chettle, Kind-Hart's Dreame (London, 1592).

35 René Weis, Shakespeare Unbound: Decoding a Hidden Life (New York: Henry Holt and Company, 2007), 169.

36 Aemilia Lanier, Salve Deus Rex Judaeorum (London, 1611), 41.

37 Ibid., 77.

38 Jean R. Brink, 'Domesticating the Dark Lady', in Jean R. Brink, ed., Privileging Gender in Early Modern England, Sixteenth Century Essays \& Studies 23 (1993), $96 \mathrm{ff}$.

39 Tertullian, On the Apparel of Women, I.1, www.newadvent.org/ fathers/0402.htm (accessed 5 May 2013). 
40 Felecia McDuffie, 'Augustine's Rhetoric of the Feminine in the Confessions: Women as Mother, Woman as Other', in Judith Stark, ed., Feminist Interpretations of Augustine (New York: Pennsylvania State University Press 2007), 106. Even the great Thomas Aquinas (1225-74) held bizarre ideas about sex and reproduction: 'woman is defective and misbegotten, for the active force in the male seed tends to the production of a perfect likeness in the masculine sex; while production of woman comes from a defect in the active force or from some material indisposition.' Summa Theologica, Ia q.92, a.1, www.newadvent.org/ summa/ (accessed 11 August 2011).

41 John Knox, The First Blast of the Trumpet against the Monstrous Regiment of Women (Geneva, 1558).

42 Lanier, Salve Deus, 19-25.

43 Kate Emery Pogue, Shakespeare's Friends (Westport, CT: Praeger, 2006), 63-5.

44 Some believe the liaison began in 1582 when Emilia was thirteen.

45 Woods, The Poems of Aemilia Lanier, 18.

46 Simon Forman, Diaries, Bodleian Library, Oxford, MS Ashmole 200, fol. $100 v$.

47 Ibid.

48 WallaceT.MacCaffrey,'Carey,Henry,first Baron Hunsdon(1526-1596)', Oxford Dictionary of National Biography, first published 2004; online edition, www.oxforddnb.com/view/article/4649? docPos=15 (accessed 21 June 2012), cites R. Naunton (1649), 102.

49 Forman, Diaries, fol. $100 v$.

50 Ibid., fol. 201.

51 Hutson, 'Lanier [née Bassano], Emilia'.

52 A survey by the author of Michele Marripodi's panel on 'Shakespeare and Italy' at the International Shakespeare Conference (Prague, 19 July 2009) revealed that all ten panellists believed Shakespeare read Italian.

53 Steve Sohmer, Shakespeare for the Wiser Sort (Manchester: Manchester University Press, 1999), 55 ff.

54 Bevington, 'Dark Lady', 22.

55 Text and lineation from Stanley Wells, Gary Taylor, John Jowett and William Montgomery, eds, William Shakespeare: The Complete Works, 2nd edition (Oxford: Oxford University Press, 2005).

56 A more cogent and simpler explanation for Jessica's flight is that she, like Portia, has heated blood, and bridles at being curbed by a father's will.

57 The Geneva text reads: 'A bastard shall not enter into the Congregation of the Lord: euen to his tenth generation shall he not enter into the Congregation of the Lord.' 
58 There is also an Aemilia in The Comedy of Errors, which is variously dated 1589-95, and an Amelia in The Winter's Tale (1611); the female lead of Two Noble Kinsmen (1613-14) is named Emilia.

59 In Sonnet 131 it is not only the lady who is 'black', i.e. dark-complexioned, but her deeds. In Sonnet 132 her blackness becomes the paradigm of beauty. But by Sonnet 147 she takes on an even darker coloration: 'For I have sworn thee fair and thought thee bright. Who art as black as hell as dark as night' (13-14).

60 Janet Adelman, Blood Relations: Christian and Jew in The Merchant of Venice (Chicago: University of Chicago Press, 2008), 79.

61 Numbers 11:5.

62 Rabbi Arthur Segal, http://rabbiarthursegal.blogspot.com (accessed 6 June 2013).

63 James Shapiro, Shakespeare and the Jews (New York: Columbia University Press, 1997), 36.

64 Martin Luther, That Jesus Christ was Born a Jew (Wittenberg: Cranach \& Doring, 1523).

65 See Sohmer, Wiser Sort, 38. Some scholars believe the sonnets were written during the closings of the theatres in 1592-94. But it is possible that the dark lady sequence was written later, perhaps as late as 1596, the year in which Shakespeare wrote and set the action of Merchant.

66 The name 'virginals' likely derives from the Latin virga signifying the rods which were driven by the keys. More wistfully, the name may be a reflection on the instrument's delicate sound, which is likened to the voices of young girls. 